\title{
Analysis of the prevalence of selected qualitative deviations in slaughter poultry in Poland in 2016-2019 \\ Krzysztof Górski*
}

\begin{abstract}
The aim of the study was to analyse the results of official post-mortem inspections of hens, chickens, turkeys, ducks and geese carried out in poultry slaughterhouses in Poland by the Veterinary Inspection in 20162019. The data from the sanitary and veterinary survey were taken from annual reports drawn up by the General Veterinary Inspectorate (RRW-6) in 2016-2019. During this period, nearly 900 million hens, 206 million turkeys, 122 million ducks, 63 million geese, and over 5.7 billion slaughter chickens were slaughtered under veterinary supervision. Symptoms or lesions were found in almost 2.6 million hens $(0.29 \%), 1.8$ million turkeys $(0.86 \%)$, 792 thousand ducks $(0.65 \%), 185$ thousand geese $(0.29 \%)$ and over 27.3 million chickens
\end{abstract}

$(0.48 \%)$. The main causes of confiscation were emaciation $(0.14 \%)$, incomplete loss of blood $(0.06 \%)$, and septicaemia and pyaemia $(0.07 \%)$. Quality deviations in the form of emaciation or incomplete loss of blood of slaughtered animals indicate shortcomings during rearing or transport of animals for slaughter. Therefore, there may be legitimate concerns about the appropriate level of animal welfare. The size of overall losses in poultry is determined by the disqualification of chickens, due to slaughter size in comparison with other species. The confiscation of such a large number of chickens deserves greater attention to determine the causes involved.

Key words: poultry; sanitary and veterinary examination; lesions; quality deviations

\section{Introduction}

Ensuring the health of slaughter poultry is of great importance in securing healthy food, since poultry meat is characterized by constantly increasing consumption (Fehlhaber, 1996). According to the United States Department of Agriculture (USDA), global poultry production has grown steadily over the past 30 years, from 7.47 million tonnes in 1970 to 40 million tonnes at the end of the $20^{\text {th }}$ century (Santana et al., 2008). In 2014, Poland became the largest poultry meat producer in the EU, further reinforcing its position

Krzysztof GÓRSKI*, PhD, Associate Professor, (Corresponding author, e-mail: krzysztof.gorski@uph.edu. pl), Faculty of Agrobioengineering and Animal Sciences, Institute of Animal Science and Fisheries, Siedlce University of Natural Sciences and Humanities, Poland 
on the market in the following years. According to Statistics Poland (GUS, 2017), the production of poultry meat amounted to about 2.8 million tons in 2017, predominantly broiler chicken production. Such good results were achieved despite the threat of influenza to bird health. Bird flu remains a huge threat, detected in 43 countries in Africa, Asia, Europe and the Middle East in 2016 (Mroczek, 2017). On each continent, the disease was caused by a different virus serotype, or the same serotype transmitted over long distances. The $\mathrm{H}_{5} \mathrm{~N}_{5}$ serotype was first identified in Europe as a threat not only to animals, but also to humans. As a result, more than 23 million poultry animals were liquidated, and 119 human deaths were reported (Lis and Górski, 2018).

In 2016, an increase in poultry meat production was observed on European Union markets. The reason for this phenomenon was the low prices of cereals and animal feed and the recovery of trade. The largest increase in the production of poultry meat was observed in Poland and Croatia, while a large decline in production was observed in Slovakia and Romania (Judzińska, 2017).

In 2017, the per capita consumption of poultry meat was about $30 \mathrm{~kg}$, an increase of more than $18 \%$ over 2011 (KRD-IG, BGŻ BNP Paribas, 2018). The increase in the consumption of poultry meat in Poland is a result of changes in eating habits and culinary preferences, and lower prices in comparison with other meats. Poultry meat is characterized by a relatively low fat and cholesterol content and high protein (Zdanowska-Sąsiadek et al., 2013). In 2017, poultry was exported most to European Union countries, where the largest recipients were Germany (169.8 thousand tons) and United Kingdom (95.9 thousand tons) (NPC-CC, 2018). It should be noted that progress in poultry production worldwide, including Poland, is the result of ensuring good health of both chicks and adult birds, taking prophylactic measures, ensuring quick and effective diagnostics and elimination of threats, among other things. The testing of slaughter animals and meat is a tool to reduce risks to consumer safety and health (Januskeviciene et al., 2010; Huneau-Salaün et al., 2014; Alpigiani et al., 2017).

The aim of this study was to analyse the results of official postmortem inspections of hens, chickens, turkeys, ducks and geese carried out by the Veterinary Inspection in poultry slaughterhouses in Poland in 2016-2019.

\section{Material and Methods}

The data from the sanitary and veterinary survey were taken from annual reports drawn up by the General Veterinary Inspectorate (RRW6) in 2016-2019. The analysis included quality-related deviations, such as emaciation, incomplete loss of blood, and septicaemia and pyaemia. The analysis of test results included the number of animals tested, the number of carcasses found with quality deviations and the number of carcasses declared unfit for consumption. The material collected was compared according to the frequency of pathological lesions found in the sanitary and veterinary examination of slaughter poultry, and then their percentage structure in individual voivodeships was determined.

\section{Results and Discussion}

Between 2016 and 2019, almost 900 million hens, more than 5.7 billion slaughter chickens, 206 million turkeys, 122 million ducks and 63 million geese were slaughtered under veterinary supervision (Table 1).

Symptoms or lesions were found in nearly 2.6 million hens $(0.29 \%), 1.8$ million turkeys $(0.86 \%), 792$ thousand 
Table 1. The prevalence of symptoms or lesions in slaughter poultry in 2016-2019 in Poland

\begin{tabular}{|c|c|c|c|c|c|}
\hline \multirow{2}{*}{$\begin{array}{c}\text { Poultry } \\
\text { species }\end{array}$} & $\begin{array}{c}\text { Number of } \\
\text { examined } \\
\text { animals }\end{array}$ & \multicolumn{2}{|c|}{$\begin{array}{c}\text { Number and percentage } \\
\text { of animals with lesions or } \\
\text { pathological symptoms }\end{array}$} & \multicolumn{2}{|c|}{$\begin{array}{c}\text { Number and percentage } \\
\text { of carcasses unfit for }\end{array}$} \\
\cline { 3 - 6 } consumption
\end{tabular}

Table 2. The prevalence of selected quality deviations of slaughter poultry carcasses in 2016-2019

\begin{tabular}{|c|c|c|c|c|c|c|}
\hline \multirow{2}{*}{$\begin{array}{c}\text { Poultry } \\
\text { species }\end{array}$} & \multicolumn{2}{|c|}{ Emaciation } & \multicolumn{2}{c|}{ Incomplete loss of blood } & \multicolumn{2}{c|}{$\begin{array}{c}\text { Septicaemia and } \\
\text { pyaemia }\end{array}$} \\
\cline { 2 - 7 } & number & $\%$ & number & $\%$ & number & $\%$ \\
\hline Hens & $1,532,731$ & 0.17 & 281,043 & 0.03 & 76,200 & 0.008 \\
\hline Chickens & $7,779,227$ & 0.14 & $3,847,824$ & 0.07 & $4,600,311$ & 0.08 \\
\hline Turkeys & 510,822 & 0.25 & 184,913 & 0.09 & 48,400 & 0.02 \\
\hline Ducks & 199,632 & 0.16 & 60,240 & 0.05 & 357,471 & 0.29 \\
\hline Geese & 49,211 & 0.08 & 13,659 & 0.02 & 62,248 & 0.1 \\
\hline
\end{tabular}

ducks $(0.65 \%), 185$ thousand geese $(0.29 \%)$ and over 27.3 million chickens $(0.48 \%)$ (Table 1$)$. The highest percentage of carcasses declared unfit was recorded among ducks (0.65\%), and the lowest among hens and geese $(0.29 \%)$.

The prevalence of quality deviations of poultry carcasses in 2016-2019 was presented in Table 2.

The main causes of confiscation were emaciation $(0.14 \%)$, incomplete loss of blood $(0.06 \%)$, and septicaemia and pyaemia $(0.07 \%)$. When comparing the slaughter and confiscation numbers of slaughter poultry in 2016-2019 with the data from 1996-1999, the number of birds slaughtered increased more than sixfold, though the percentage of carcasses declared unfit did not change (0.46\% in 1996-1999; 0.44\% in 2016-2019) (Libelt, 2001). Freitas (2015) classifies emaciation as a lesion, characterized by a reduction in muscle mass, identified mainly in the pectoral muscles. Paschoal et al. (2012) identified emaciation as the third most common reason for declaring poultry meat unfit for consumption in Northeast Parana, with a frequency of 15.82\%. Ansari-Lari and Rezagholi (2007) also reported that emaciation $(37.7 \%)$ was the most important cause of rejection. Emaciation is caused by poor flock management, and is associated with chick quality, environmental temperature, stocking density and feed consumption (Ghaniei et al., 2016). Septicaemia is manifested by a group of clinical signs such as congested, darkened muscles with inflammatory lesions (Gracey et al., 1999). In a study by Ghaniei et al. (2016), septicaemia was the most common cause of carcass rejection $(34.6 \%$ of total rejections).

The quality deviations observed for years as a reason for rejection deserve more attention, and should be eliminated 


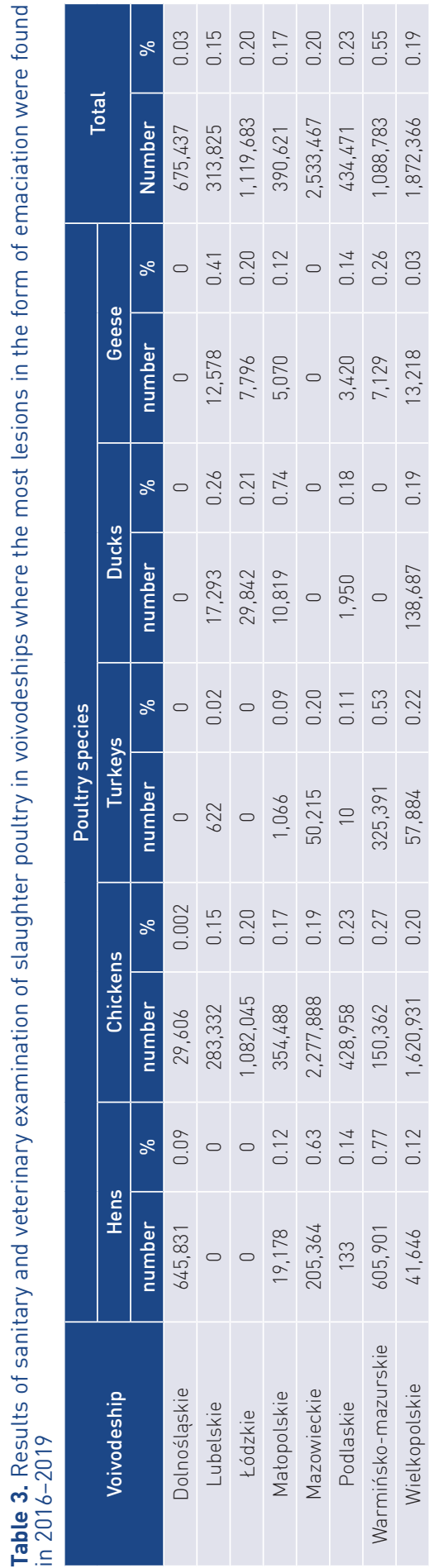

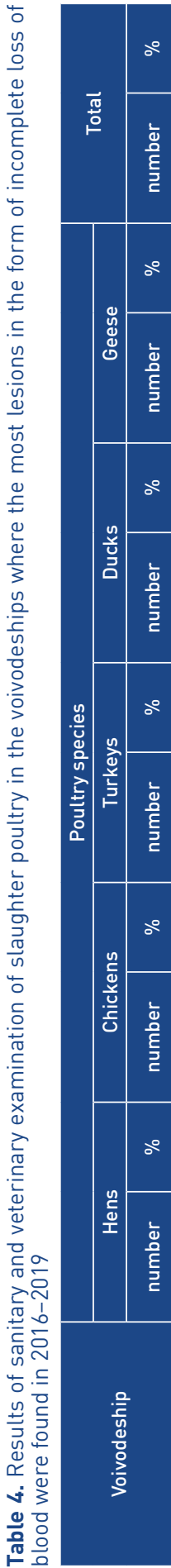

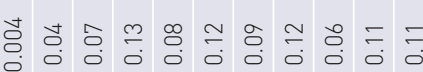
m

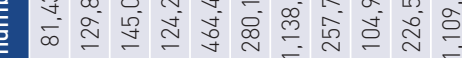
- $0 \frac{0}{0} 0.00 \%$

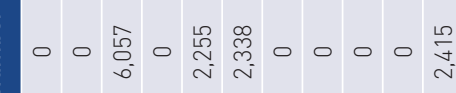

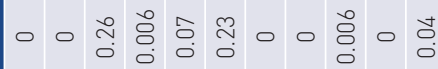

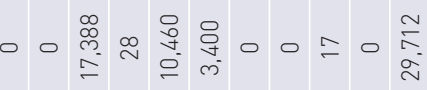

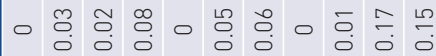

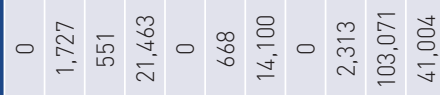

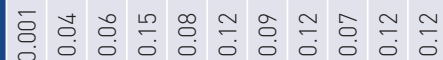

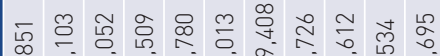

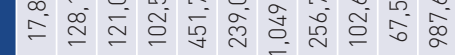

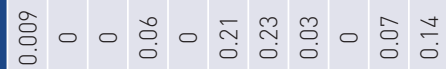

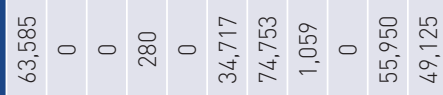
\begin{tabular}{|l|l|l|l|l|l|l|l|}
\hline & \\
\hline
\end{tabular} 

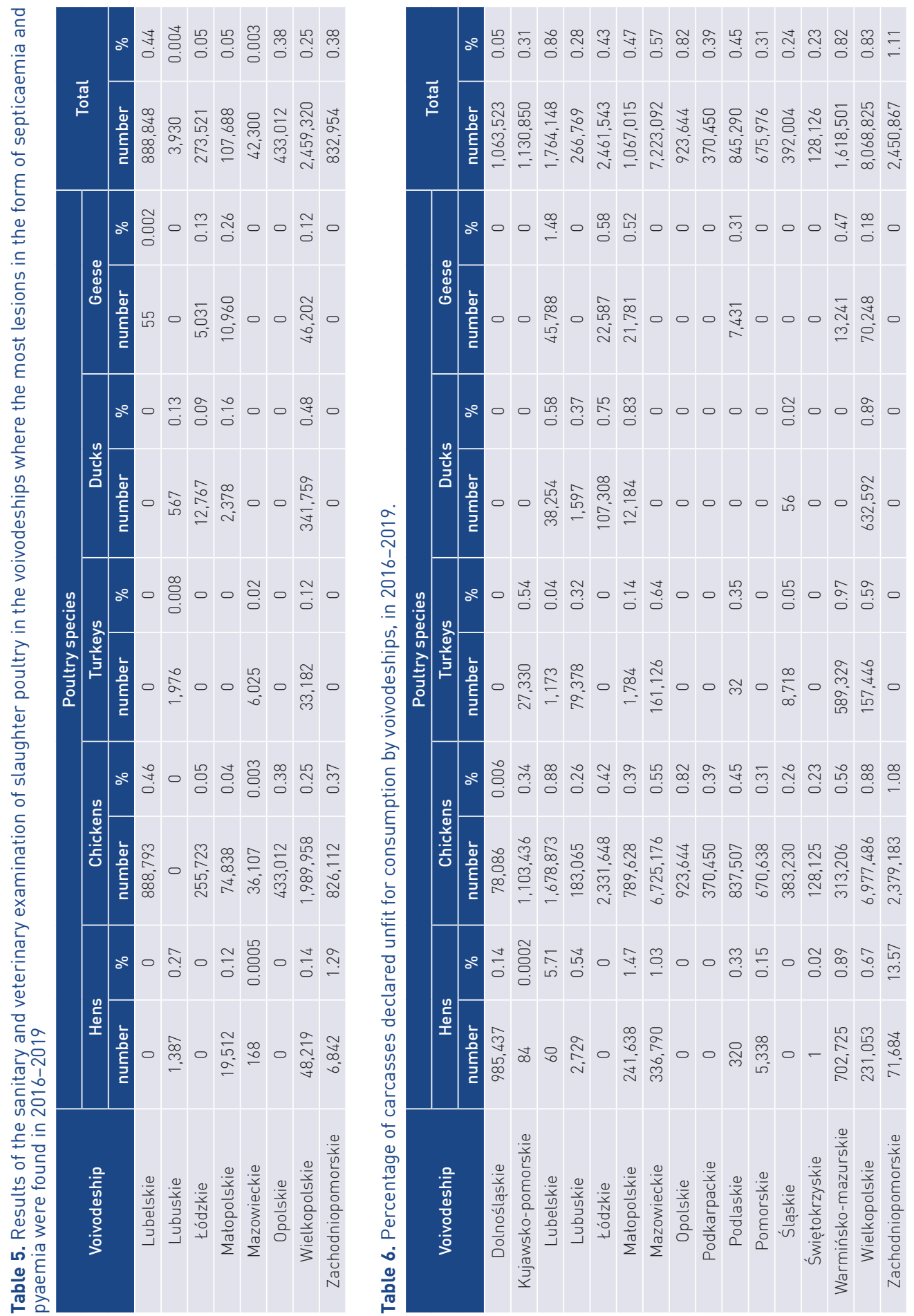
(Lis, 2002). The primary problem is, and will always remain, microbiological contamination of poultry during the slaughtering process (Fehlhaber, 1996). This makes it necessary to constantly monitor the sanitary condition of business entities engaged in slaughtering, cutting carcasses and processing poultry meat, taking care of maintaining cleanliness and order, and to control the prevalence of poultry diseases throughout the country (Baracho et al., 2006).

The frequency of quality deviations of slaughter poultry in Poland also showed territorial diversity. The presence of the most significant lesions of slaughter poultry in specific regions of Poland is presented in Tables 3-5.

The highest percentage of quality deviations in the form of emaciation was found in the Warmińsko-mazurskie Voivodeship $(0.55 \%)$ and the lowest in Dolnośląskie Voivodeship (0.03\%).

Table 4 presents the data showing the frequency of incomplete loss of blood in poultry by particular voivodeships.

Table 4 shows that the highest percentage of these quality deviations occurred in Lubuskie Voivodeship $(0.13 \%)$ and the lowest in Dolnoślackie Voivodeship (0.004\%).

Table 5 presents data showing the frequency of septicaemia and pyaemia in slaughter poultry in specific voivodeships.

The highest percentage of changes in the form of septicaemia and pyaemia was found in the Lubelskie Voivodeship $(0.44 \%)$ while the lowest incidence was found in the Mazowieckie $(0.003 \%)$ and Lubuskie Voivodship (0.004\%).

In $2016-2019,0.48 \%$ of all examined carcasses were declared unfit for consumption. Table 6 provides the number and percentage structure of poultry carcasses declared unfit for consumption by voivodeships.

This data shows that the incidence of poultry carcasses considered unfit for consumption was highest in voivodeships in the western and central part of Poland, i.e., from over 2.4 million in the Zachodniopomorskie and Łódzkie Voivodeships, to over 7.2 million in the Mazowieckie and over 8 million in the Wielkopolskie Voivodeships.

In conclusion, an excessively large number of slaughter poultry in Poland still shows disease lesions, and the numbers in some voivodeships are alarming. Quality deviations found before and after slaughter are not only the basis for assessing the rearing technology, transport or storage conditions. They also provide information on animal health status and welfare. With consideration of the above, research in this area should be carried out systematically and significantly expanded. Quality deviations in the form of emaciation or incomplete loss of blood of slaughtered animals indicate shortcomings during rearing or transport of animals for slaughter. Therefore, there may be legitimate concerns about the appropriate level of animal welfare. The size of the overall losses in poultry is determined by the disqualification of chickens due to slaughter size in comparison with other species. The rejection of such a large number of chickens deserves more attention to determine the causes involved.

\section{References}

1. ALPIGIANI, I., J. C. ABRAHANTES, V. MICHEL, A. HUNEAU-SALAÜN, M. CHEMALY, L.J. KEELING, A. GERVELMEYER, C. BACCI, F. BRINDANI, S. BONARDI and F. BERTHE (2017): Associations between animal welfare indicators and Campylobacter spp. in broiler chickens under commercial settings: A case study. Prev. Vet. Med. 147, 186-193.

2. ANSARI-LARI, M. and M. REZAGHOLI (2007): Poultry abattoir survey of carcass condemnations in Fars province, southern Iran. Prev. Vet. Med. 79, 287-293.

3. BARACHO, M. S., G. A. CAMARGO, A. M. C LIMA, J. F. MENTEM, D. J. MOURA, J. MOREIRA and I. A. NAAS (2006): Variables impacting poultry meat quality from production to pre-slaughter: A review. Braz. J. Poultry Sci. 8, 201-212. 
4. FEHLHABER, K. (1996): Problemy mikrobiologiczne u drobiu rzeźnego. Med. Weter. 52, 758-762.

5. FREITAS, L. S. (2015): Causas de condenacoes postmortem de frangos. Monografia - Universidade Federal do Rio Grande do Sul. Porto Alegre, 45p.

6. GHANIEI, A., S. MOJAVERROSTAMI and P. SEPEHRNIA (2016): Survey of poultry carcass condemnations in abattoirs of West Azerbaijan Province (North West of Iran). J. Hellenic Vet. Med. Soc. $67,183-188$.

7. GRACEY, J. F., D. S. COLLINS and R. J.HUEY (1999): Poultry production, slaughter and inspection. In: Meat Hygiene. $10^{\text {th }}$ ed., W.B. Saunders Company LTD, Philadelphia, pp. 261-287.

8. GUS - Główny Urząd Statystyczny. Rocznik Statystyczny Leśnictwa. Warszawa 2019 [Central Statistical Office, Warsaw 2019].

9. HUNEAU-SALAÜN, A., K. D.C.STÄRK, A. MATEUS, C. LUPO, A. LINDBERG and S. LE BOUQUINLENEVEU (2015): Contribution of meat inspection to the surveillance of poultry health and welfare in the European Union. Epidemiol. Infect. 143, 2459-2472.

10. JANUSKEVICIENE, G., V. PAULAUSKAS, J. DAILIDAVICIENE and V. JUOZAITIENE (2010): Analysis of pathologic lesions in the livestock and poultry slaughtered in the meat establishments of Lithuania. Vet. Med. Zoot. 52, 33-42.

11. JUDZIŃSKA, A. (2017): Produkcja mięsa w Unii Europejskiej w 2016 r. Gospod. Mięsna 68, 24-26.

12. KRD-IG, BGŻ BNP Paribas. Raport - rynek mięsa drobiowego, Warszawa, 2018.

13. LIBELT, K. (2001): Występowanie odchyleń jakościowych u drobiu rzeźnego w Polsce w latach 1996-1999 [Qualitative changes in poultry slaughtered in Poland between 1996-1999]. Med. Weter. 57, 102-104.
14. LIS, H. (2002): Wyniki badania sanitarnoweterynaryjnego drobiu rzeźnego w Polsce w $2000 \mathrm{r}$. [Results of sanitary examinations of poultry slaughtered in Poland during 2000]. Med. Weter. 58, 112-113.

15. LIS, H. and K. GÓRSKI (2018): Wyniki badania sanitarno-weterynaryjnego drobiu rzeźnego w Polsce w 2016 r. [The results of sanitary investigations on slaughtered poultry in Poland in 2016]. Życie Wet. 93, 121-123.

16. MROCZEK, R. (2017): Ocena stanu produkcji oraz ceny żywca rzeźnego w Polsce w 2017 r. Gospod. Mięsna 68, 65-67.

17. NPC-CC. National Poultry Council-Chamber of Commerce (KRD-IG), Warsaw, 2018.

18. PASCHOAL, E. C., L. K. OTUTUMI and A. P. SILVEIRA (2012): Principais causas de condenacoes no abate de frangos de corte de um abatedouro localizado na regiao noroeste do Parana, Brasil. Arq. Cien. Vet. Zool. UNIPAR 15, 93-97.

19. RRW-6. Sprawozdania $\mathrm{z}$ wyników urzędowego badania zwierząt rzeźnych i mięsa za 2016, 2017 2018 i 2019 rok [Veterinary statistical reporting]. Warszawa, Główny Inspektorat Weterynarii.

20. SANTANA, A. P., L. S. MURATA, C. G. FREITAS, M. K. DELPHINO and C. M. PIMENTEL (2008): Causes of condemnation of carcasses from poultry in slaughterhouses located in State of Goias, Brazil. Ciencia Rural, Santa Maria 38, 2587-2592.

21. ZDANOWSKA-SĄSIADEK, Ż., M. MICHALCZUK, M. MARCINKOWSKA-LESIAK and K. DAMAZIAK (2013): Czynniki kształtujące cechy sensoryczne mięsa drobiowego [Factors determining the sensory quality of poultry meat]. Bromat. Chem. Toksykol. 3, 344-353.

\section{Analiza prevalencije izabranih odstupanja kvalitete peradi za klanje u Poljskoj u razdoblju 2016. 2019.}

Dr. sc. Krzysztof GÓRSKI, izvanredni profesor, Fakultet agrobioinženjerstva i animalnih znanosti, Institut za animalnu znanost i ribarstvo Sveučilišta prirodnih i humanističkih znanosti Siedlce, Poljska

Cilj je ove studije bio analizirati rezultate službene obdukcijske inspekcije kokošiju, pilića, purica, pataka i gusaka koje je u razdoblju 2016.-2019. godine obavila veterinarska inspekcija u klaonicama peradi u Poljskoj. Analizirani su podatci sanitarnog i veterinarskog nadzora uzeti iz godišnjih izvješća koje je sastavio Glavni veterinarski inspektorat (RRW6) u razdoblju 2016.-2019. godine. Između 2016. i 2019. godine, gotovo 900 milijuna kokošiju, više od 5,7 milijardi pilića za klanje, više od 206 milijuna purica, više od 122 milijuna pataka i više od 63 milijuna gusaka zaklano je pod veterinarskim nadzorom. Simptomi ili lezije pronađeni su u gotovo 2,6 milijuna kokošiju $(0,29 \%)$, više od 27,3 milijuna pilića $(0,48$ $\%)$, gotovo 1,8 milijuna purica $(0,86 \%)$, gotovo
729 tisuća pataka $(0,65 \%)$ te gotovo 185 tisuća gusaka $(0,29 \%)$. Glavni uzroci konfiskacije bili su propadanje $(0,14 \%)$, nepotpun gubitak krvi $(0,06 \%)$, kao i septikemija i pijemija $(0,07$ $\%)$. Odstupanja kvalitete u obliku propadanja ili nepotpunog gubitka krvi zaklanih životinja ukazuju na grješke tijekom uzgoja ili prijevoza životinja za klanje pa stoga može postojati opravdana zabrinutost u svezi prikladne razine dobrobiti životinja. Količina sveukupnih gubitaka u peradarstvu određuje se diskvalifikacijom pilića, zbog količine klanja u usporedbi s ostalim vrstama. Konfiskacija takvog velikog broja pilića zaslužuje više pozornosti, kao i pronalaženja razloga za to.

Ključne riječi: perad, sanitarni $i$ veterinarski pregled, lezije, odstupanja kvalitete 